\title{
Pan-european transport corridors in the policy of the European Union
}

\author{
Mirosław CZECH *1 \\ ${ }^{1}$ University of Rzeszow Faculty of Political Science, Rzeszow, Poland
}

\begin{abstract}
The issue of organizing efficient transport with in Europe is one of the areas of the common policy of the European Union, shaped for over 30 years. Poland has been participating in this creative processsince May 1, 2004. The intensity of the development of transport and economy of individual countries that do not only belong to the Community has a significant impact on changes in the European Union's transport policy aimedatimproving the course of pan-European transport corridors. In parallel with the creation of an effective European transport network, the rapid economic development of the regions belonging to the Union, including Poland, is becoming in creasingly important. The aim of the article is to discuss the issue of the development of trans-European transport corridors, which also pass through the territory of Poland, and to present changes in EU policy concerning the shaping of transport infrastructure in Europe, as a result of which a single transport network is to be created in the near future, meeting the communication and economic needs of the countries belonging to the Community.
\end{abstract}

Keywords: TEN-T, transport policy, corridor, infrastructure

\section{Introduction}

The European Union's transport policy consists, among other things, of integrating the infrastructure of countries belonging to the Community and those neighbouring or close to the Union. It is worth noting that transport corridors are intended to create a coherent, uniform and effective European transport system (combining road, water and rail traffic), which was originally defined during the 2nd Pan-European Transport Conference held in Crete in March 1994 and further specified during the 3rd Pan-European Transport Conference held in Helsinki in 1997. It was then decided to locate 10 Pan-European corridors running through Central and Eastern European countries [2]. Together, they were to form the Trans-European Transport Network [14], integrating territories belonging to the European Union and border areas. As a result of the revision of the guidelines for the TEN-T network completed in 2013, its new layout was established on the territory of the European Union Member States. This layout includes the core network, which forms the basis for the development of the transport network, concentrating Union action mainly on cross-border sections, missing links, multimodal connections and major 'bottlenecks', as well as the comprehensive network, which will in future provide a connection to all sub-regions of the Community [13] . Currently, as part of the European Commission's activities, Member States are being consulted on the preparation of the Regulation on Union guidelines for the development of the trans-European transport network, amending Decision No 661/2010/EU.

The analyses of Union policies carried out for the purposes of this article indicate the objectives and importance of the international connections established on the European continent, taking into account their further development and the financial resources made for the proper establishment and functioning of the trans-European corridors within the European Union. An important part of the analysis is also the characteristics of the Union's transport policy concerning the designated pan-European transport corridors $[3-6,11,12,15,16]$.

\section{Transport corridors and their importance}

In shaping transport policy, the European Union has shared competences, which means that Member States exercise their own competences unless the Union develops a unified transport policy and common strategies in this area. The

${ }^{*}$ Corresponding author: E-mail address: czech_m@o2.pl (Mirosław CZECH)

https://doi.org/10.37105/iboa.100

Received 15 January 2021

Available online 31 March 2021

ISSN 2450-1859, eISSN 2450-8721

Published by Centrum Rzeczoznawstwa Budowlanego 
Treaty on the Functioning of the European Union (TFEU) lays down the basis for the establishment of a transEuropean transport network [14], i.e. an integrated multimodal network allowing the rapid and seamless movement of people and goods within the Community. This network consists of two levels. The core network, which is planned to be completed in 2030, comprises the strategically most important connections and nodes throughout the European Union. The comprehensive network, which is planned to be completed in 2050, has a wider objective of ensuring accessibility and connectivity for all Union regions (ETO, 2018, pp. 4-5).

The smooth functioning of transport determines the economic development of individual EU regions. Investment in transport and transport infrastructure in the European Community accounts for approximately 1\% of EU GDP. The Union's transport policy operates on the basis of principles relating, among other things, to the international carriage of goods, the formal and legal conditions under which carriers operate transport services on the territory of a Member State in which they are not established and to technologies which enhance transport safety. "However, as H. Klimek [7]demonstrates, the creation of a single European transport network encounters a number of difficulties, connected with the self-interest of the Member States and the largely incoherent structure of the existing communication layouts of transit roads".

It is safe to say that the concept of the trans-European transport network has served as a preliminary material for the project to consolidate the transport infrastructure network in Europe. The plan to strengthen the transport network, formulated in 1997[9], assumed the establishment of the so-called Pan-European Transport Corridors and Pan-European Transport Areas on the border of the European Union and neighbouring areas on the southern and eastern side. The concept of pan-European transport corridors provided for the extension of the TEN-T network to the territories of candidate countries to the Community, in accordance with the TINA (Transport Infrastructure Needs Assessment) programme introduced in 1996, which consisted in indicating the directions of the largest transport flows in the area of Central and Eastern Europe, defining a network of transport connections along the global directions of the flow of goods and people and planning the necessary infrastructure investments related to it.

It is worth noting that the key importance of transport corridors for the development of the European Community, especially in the area of impact on spatial organisation, has also been defined in over a dozen official documents which formulate the principles for the spatial development of Europe, the territory of the EU, and also the Baltic Sea area, as a region for cooperation between EU Member States and institutions from Central and Eastern European countries, in the field of spatial planning, among other things. After analysis, I would like to point to the issue of optimum use of the multimodal potential of transport infrastructure, the development of which is the basis for the operation of the TEN-T network, as a result of:

- transfer of the burden of handling transit traffic from road to rail and inland water corridors

- inclusion of multimodal airports and seaports in the network, complementing land transport based on coastal shipping and regional air connections

- creation of (transhipment) hubs for goods and passengers, in places particularly suitable for changing modes of transport

- ensuring access to the transit transport networks for areas not in their immediate vicinity through regional public transport (rail, bus and air)

The main tasks of the pan-European transport corridors are to increase the spatial integration of the European continent, to strengthen and improve the accessibility of labour and sales markets and to increase spatial cohesion. "In the article H. Klimek[7] recalls the position of K. Wojewódzka - Król and R. Rolbiecki [18] that the development of transport infrastructure contributes to:

- reducing disparities in the level of economic development of regions (e.g. by increasing attractiveness and creating favourable conditions for potential investors, attracting accompanying investments, e.g. in service infrastructure)

- developing the building materials industry and the construction services sector

- alleviating certain socio-economic problems, e.g. unemployment, improving transport accessibility of various places

- increasing the mobility of people

- reducing external transport costs

- stimulating cooperation between border regions 
- stimulating international trade in goods (especially through the construction of international transport connections and the elimination of obstacles at border crossings, which encourages the free movement of goods and people) and developing international cooperation"

In the author's opinion [7], the functioning of a network of fast and efficient connections between European cities, guaranteeing the efficient movement of freight and passengers, as well as optimal use of the potential of various means of transport, has an impact on faster economic development of areas on the outskirts of the European Union, which often have an underdeveloped network of transport connections. In accordance with the Community's current assumptions, this measure is to be accompanied by strengthening and expansion of regional transport networks. This applies particularly to the so-called 'gateway cities', which means cities opening up access to European Union territory. These include large port centres, intercontinental airports, centresorganising major trade fairs and cultural events, as well as those metropolitan areas which, lying on the borders of the European Union, take a competitive advantage due to low labour costs and specific links with economic centres outside its borders . The trans-European TEN-T network layout has been designed to ensure compatibility with the main transport routes of current and future Community Member States".

An integral component of the TEN-T transport network is not only the connections essential for the functioning of the European Community, including the most important centralised linear facilities, i.e. roads, railways, air, sea and river routes, but also nodal infrastructure facilities, freight transhipment sites and points of interchanges, i.e. road and rail transhipment hubs, airports, maritime and inland ports. Along with the development of technological progress, an important element for communication are also intelligent transport systems (ICT networks), which have a significant impact on increasing traffic safety, improving the capacity of communication networks and environmental protection.

TEN-T core network corridors In order to systematise and effectively implement uniform international transport connections and to speed up preparatory work on major infrastructure projects which are important for the economic development of the Union, the European Community has designated and introduced transport core network corridors. The TEN-T network corridors are intended to coordinate various projects at supranational level and, according to the European Community's intentions, should be completed by 2030. According to the Union's objectives, the implementation of the TEN-T corridors is intended to solve the problem of the existence of the so called 'communication bottlenecks' on the main transport network, to ensure faster and better cross-border connections and to improve the efficiency and sustainability of the transport system in global terms. Nine core network corridors have been established instead of the 30 TEN-T priority projects originally adopted (Figure 1): Atlantic, Baltic-Adriatic, Mediterranean, North Sea-Baltic, North Sea-Mediterranean Sea, Eastern Mediterranean, Rhine-Alps, Rhine-Danube, Scandinavian-Mediterranean.

Two of them form the core TEN-T network in Poland. They are the Baltic-Adriatic corridor connecting Polish seaports, via the Czech Republic, Slovakia, Austria and Italian Adriatic ports, and the North Sea-Baltic Sea corridor connecting Finland, Estonia, Latvia, Lithuania and Poland with seaports in Belgium, the Netherlands and Germany.

\section{European Union policy and emphasis on transport issues (2014-2020)}

It is easy to see that the policy on the development of transport corridors is a response to the analysis of transport flows taking place within the European Community, which was carried out taking into account the economic needs of individual regions, the quality of the technical infrastructure supporting them and the ICT traffic management systems in place. The Union's policy for the further, forward-looking shaping and development of transport corridors has a broad aspect, due to the economic and social transformations that are constantly taking place in the Member States of the Community, and therefore requires the use of uniform spatial planning instruments in a global international system. Bearing in mind the integrated nature of EU transport policy, interregional and local actions were introduced in the sphere of education, culture, science and development, as well as projects strengthening the competitive position of smaller regional centres, often poorly urbanised and far from the centre of the EU.

For many years now, the European Commission has been trying to solve the problem of the growing volume of road traffic and the related need to improve road safety in official documents presenting a strategy for transport development and logistics. One of the first ideas published in the White Paper was to increase the share of alternative transport for road transport modes, with a particular emphasis on rail transport. This is directly related to the concept of sustainable transport, which assumes an improvement in environmental conditions by, among other things, reducing emissions of carbon compounds in exhaust fumes. 


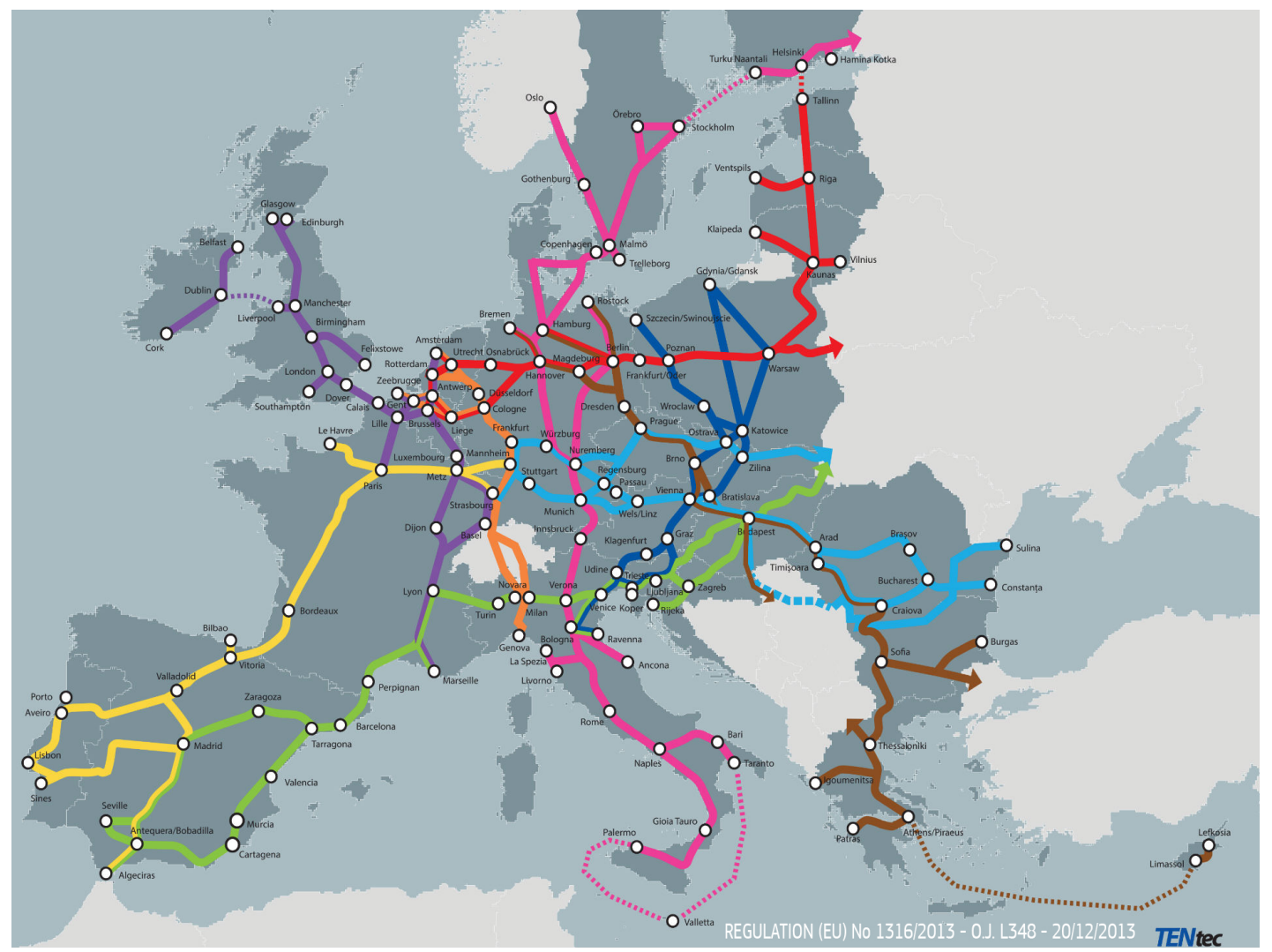

Figure 1. TEN-T core network corridors [14]

The first work on planning and subsequent implementation of the Union's global transport infrastructure in its current form started in 2001, when the European Commission began to review the guidelines in force at the time, applicable within the Trans-European Transport Network TEN-T. The consultation process was then launched, with the participation of the Member States and the candidate countries to the Community, as a result of which, in April 2004, the European Parliament and the European Council took a Decision No 884/2004/EC , which outlines the future shape of the pan-European network of European Union transport corridors. "A. Lipińska-Słota [8]refers to its content, summarizing the changes introduced to the European transport network, which resulted in the creation of 30 priority axes - investments with the highest added value for the entire European Union. Out of these 30 projects, 18 were railway projects, 3 covered both rail and road routes, 2 related to inland water transport and one - maritime transport". This is essential for the creation of a complete and integrated transport network with in the European Union, which should include all Member States.

It should be stressed that the most important documents which define the objectives of EU transport policy are the white papers published by the European Commission every ten years or so. In the current third White Paper, which was created in 2011, on the future of the transport sector by 2050, entitled 'Roadmap to a Single European Transport Area - Towards a competitive and resource efficient transport system'[17], published on 28 March 2011, the European Commission points to the situation of the transport sector undergoing a phase of transition between old and new challenges and refers to measures to overcome these difficulties [2]. In terms of transport, 10 objectives were set (inter alia to shift $30 \%$ of the volume of road freight transport to rail or water transport by 2030 , and over $50 \%$ by 2050 ; to triple the existing high-speed rail network by 2030), to shift most of its medium-distance passenger traffic to rail by 2050; to establish a fully functioning multi-modal TEN-T core network in the Union by 2030 and to establish a high-quality and efficient network including related information services by 2050, etc.). In particular, the Commission is seeking to create a true European Single Transport Area by removing persistent barriers between transport modes and national systems and supporting the integration process [10]. 


\section{EU actions on the development of major transport corridors in the years 2014-2020}

The responsibility for the development, financing and construction of transport infrastructure lies primarily with the Member States. EU funds - which must bring European added value - can only speed up actions and cover just a fraction of total needs. Nevertheless, transport policy is supported by a number of EU funding instruments, with a total value of around EUR 193 billion(Table 1) for the period 2007-2020 (ETO, 2018, p. 14).

Table 1. Budgetary resources allocated for the period 2007 - 2020 (EUR billion) 1. the seventh framework programme for research and technological development 2. including 11. 3 billion euros from the Cohesion Fund Adapted from: European Court of Auditors, based on European Commission data, EU transport in figures - statistical pocketbook 2018.

\begin{tabular}{|c|c|c|c|}
\hline Instrument & $\mathbf{2 0 0 7 - 2 0 1 3}$ & $\mathbf{2 0 1 4 - 2 0 2 0}$ & In total \\
\hline ERDF and the Cohesion Fund/ ESIF & 81.8 & 68.5 & 150.3 \\
\hline TEN-T & 8.0 & $\mathrm{~N} / \mathrm{A}$ & 8.0 \\
\hline Marco Polo & 0.5 & $\mathrm{~N} / \mathrm{A}$ & 0.5 \\
\hline Connecting Europe - transport & $\mathrm{N} / \mathrm{A}$ & $24.1(2)$ & 24.1 \\
\hline FP7(1) - transport & 4.2 & $\mathrm{~N} / \mathrm{A}$ & 4.2 \\
\hline Horizon 2020 - transport & $\mathrm{N} / \mathrm{A}$ & 6.3 & 6.3 \\
\hline In total & 94.5 & 98.9 & 193.4 \\
\hline
\end{tabular}

The conditions for establishing and financing the TEN-T core network corridors are laid down in two regulations of the European Parliament and the Council of the European Union:

- No 1316/2013 on the establishment of the new financial instrumentConnecting Europe Facility CEF (OJ EU L of 20 December 2013), the Annex to which indicates the course of those corridors and a list of projects to be financed in the first instance by the CEF. It also defines the functioning of the instrument called Connecting Europe Facility - CEF), to finance investments in the TEN-T core network corridors;

- No 1315/2013 on Union guidelines for the development of the trans-European transport network TEN-T (OJ EU L of 20 December 2013), laying down guidelines for the development of the TEN-T network. The document defines, inter alia, the definition of a project of common interest, development priorities, scope and target parameters of the TEN-T network.

Under current transport policy, a core TEN-T network has been established, the pillar of which is the nine main transport corridors: 2 corridors heading north-south, 3 corridors east-west and 4 diagonal corridors. The European Union has planned to create a coherent transport network within the 28 Member States. According to these plans, two transport corridors will pass through Poland: the Baltic-Adriatic corridor and the North Sea-Baltic Sea corridor. The plan adopted has been the first document on such a large scale since the creation of European Union transport policy in the 1980s [1].

For the implementation of this project, the European Parliament approved the financial instrument Connecting Europe Facility in a separate vote, with a total value of EUR 29.3 billion, of which EUR 26.25 billion was allocated to investment in transport sector [7]. In general, the Connecting Europeprogramme and its assumptions are also mentioned by A. Lipinska - Slota [8] in the article entitled: 'Transport corridors in the new European Union transport policy'.

The majority (78\%) of EU funds allocated to transport during the two programming periods 2007-2020 were spent under shared management (Table 2). It should be noted, however, that the proportion of funds managed directly by the Commission is increasing, with $13 \%$ for the period 2007-2013 and 31\% for the period 2014-2020. Transport was the largest area of expenditure, both for the ERDF and the Cohesion Fund, during both programming periods (24\% of total allocations in 2007-2013, 20\% in 2014-2020). Nearly half of the ERDF and Cohesion Fund spending on transport between 2007 and 2020 was allocated to road infrastructure(ETO, 2018, p.15). 
Table 2. Budgetary resources from the ERDF and the Cohesion Fund allocated to different modes of transport for the period 2007-2020 (EUR billion. Adapted from: European Court of Auditors based on European Commission data, EU transport in figures statistical pocketbook 2018.

\begin{tabular}{|c|c|c|c|c|}
\hline Mode of transport & $\mathbf{2 0 0 7 - 2 0 1 3}$ & Percentage share & $\mathbf{2 0 1 4 - 2 0 2 0}$ & Percentage share \\
\hline Road transport & 42.6 & $52 \%$ & 30.03 & $44 \%$ \\
\hline Rail transport & 23.1 & $28 \%$ & 18.6 & $27 \%$ \\
\hline Urban transport & 8.2 & $10 \%$ & 12.5 & $18 \%$ \\
\hline Ports & 3.1 & $4 \%$ & 2.0 & $3 \%$ \\
\hline Multimodal transport & 1.8 & $2 \%$ & 2.2 & $3 \%$ \\
\hline Intelligent transport systems (ITS) & 1.0 & $1 \%$ & 2.1 & $3 \%$ \\
\hline Inland waterway transport & 0.4 & $1 \%$ & 0.7 & $1 \%$ \\
\hline Air transport & 1.6 & $2 \%$ & 0.4 & $1 \%$ \\
\hline Total transport & 81.8 & $100 \%$ & 68.5 & $100 \%$ \\
\hline
\end{tabular}

As of December 2017 (Table 3), from the Connecting Europe Facility envelope (for the 2014-2020 programming period alone), projects were allocated EUR 22.3 billion (approximately $93 \%$ of its total transport budget). The majority of the projects financed cover core network corridors (79\% of the projects) and concern sustainable modes of transport such as rail and inland waterways (ETO, 2018, p.16).

Table 3. CEF financial allocations. Adapted from: European Court of Auditors based on European Commission data, EU transport in figures - statistical pocketbook 2018.

\begin{tabular}{|c|c|c|}
\hline Mode of transport & $\begin{array}{c}\text { Total increase in resources } \\
\text { (as of December 2017 in EUR billion) }\end{array}$ & Percentage share \\
\hline Rail transport & 16.4 & $74 \%$ \\
\hline Inland waterway transport & 1.7 & $8 \%$ \\
\hline Rod transport & 1.7 & $8 \%$ \\
\hline Air transport & 1.3 & $6 \%$ \\
\hline Maritime transport & 0.9 & $4 \%$ \\
\hline Multimodal transport & 0.3 & $1 \%$ \\
\hline Total transport & 22.3 & $100 \%$ \\
\hline
\end{tabular}

Increased funding for EU investment has undeniably contributed to improving the connectivity and accessibility of EU countries. For example, in 2007-2013, resources from the Cohesion Fund were used to support the construction of $3875 \mathrm{~km}$ of new roads ( $47 \%$ of which belong to the TEN-T network) and the reconstruction of more than 23000 $\mathrm{km}$ of roads, which in total represents $10 \%$ of the length of the main road network in the 15 Member States eligible for funding(ETO, 2018, p. 30).

According to the 2018 horizontal review of the European Court of Auditors', funding for transport infrastructure has tripled between 2014 and 2020 reaching EUR 26 billion compared with the previous financial perspective. At present, EU funding (up to 2020) is aimed primarily at developing the TEN-T core network, which has the greatest European added value.

The TEN-T core network provides for the implementation of:

- 94 major European ports with rail and road connections,

- 38 key airports with rail connections to major cities, 
- $15000 \mathrm{~km}$ of railways adapted for high speed,

- 35 cross-border projects aimed at removing the so-called transport bottlenecks.

The above mentioned planned investment projects, some of which have already been carried out and the rest are to be implemented, will have a positive impact on the economic development of the Member States, allowing the free transport of goods and passengers throughout the Community. The planned core TEN-T network, supplemented and interconnected into a single network with a comprehensive network planned to be implemented in the form of a supplement to regional transport routes of a sufficiently high standard and technical parameters, is intended to cover the entire territory of the Union and facilitate movement between its individual regions.

However, the further development of the pan-European transport networks requires further significant financial investment. According to the European Commission's estimates, the total value of investment needs in this area is around EUR 130 billion per year, with considerable resources being required at a later stage to maintain the infrastructure created. It is estimated that the TEN-T core network alone will represent an expenditure of around EUR 500 billion between 2021 and 2030. When the comprehensive network and other transport investments are included in the calculations, this amount rises to around EUR 1.5 trillion(ETO, 2018, p.13).

According to the draft (May 2020) budget of the European Commission for 2021, which takes into account the economic and social crisis caused by the Covid-19 virus epidemic, the Member States covered by cohesion policy should receive EUR 47.15 billion, supplemented by EUR 42.45 billion under the so-called reconstruction mechanism. The current agreement of the European Parliament and the European Council on the Multiannual Financial Framework for 2021-2027 reached on 17-21 July 2020 at the extraordinary summit of European leaders assumes that the financial envelope for implementing the Connecting Europe Facility (CEF) will be EUR 28396 million. This amount will be divided among individual sectors, with EUR 21384 million allocated to transport development, of which EUR 10000 million will be transferred from the Cohesion Fund for specific expenditure, in accordance with the CEF regulation.

\section{Conclusion}

The development of the transport network within the European Union is quite advanced, but its quality and accessibility are still not sufficient, especially among the Member States located in its eastern part. In some regions of the Union, the implementation of the TEN-T core network, which falls within a given area, has already been completed, and in other countries, especially those which have recently joined the European Union, the network of main transport links of an appropriate technical and operational standard is insufficient.

Although the TEN-T regulation defines the route of the trans-European transport corridors along which the appropriate technical infrastructure must be provided, most of the preparatory actions and the necessary financial resources for their implementation are indeed planned and provided by the individual Member States themselves. For this reason, it must be reckoned with that there may be some delays in the implementation of individual sections of the trans-European transport network, affecting the integration of the entire European communication system. This is why European Union support is an important instrument in planning, preparing and implementing the TENT network. The further development of the trans-European core and comprehensive network is dependent on the envelope to be committed under the new financial perspective 2021-2027, under the Cohesion Fund, including the contribution to the Connecting Europe Facility for transport networks, finally adopted at the extraordinary meeting of the European Council of 17-21 July 2020.

In doing so, account must be taken of the continuous increase in demand for transport services and the associated increase in vehicle traffic in transit. According to forecasts formulated by Eurostat, the years 2010 to 2050 are expected to triple $(182 \%)$ the demand for freight transport services in continental Europe. This will require the creation of new trans-European transport corridors to ensure the free movement of goods and passengers within and outside the European Union and the need to finance further transport links (Wakefield, 2019).

The greater use of multimodal transport, which has been one of the main objectives of the EU transport policy for many years, can play an important role in moving away from purely road transport. Multimodality is the use of different means of transport during one journey. Although some progress has been made in this respect in recent years, multimodal transport is still not widely used in Europe. Funding for multimodality projects comes mainly from the ERDF and the Cohesion Fund, and their allocation for the period 2007-2020 is approximately EUR 4 billion (ETO, 2018, s. 23). It is to be hoped that the new financial perspective, covering the period 2021-2027, adopted by the European Parliament and the European Council at the extraordinary meeting of the European Council of 17-21 
July 2020, will continue the activities related to the implementation and development of the Pan-European transport corridors, including multimodal transport.

\section{References}

1. 9 European transport corridors 2013. https://transinfo.pl/9-europejskich-transportowych-korytarzy_ more_43462.html\#.

2. Coito, E., Klaus, B. \& Blaser, W. titleThematic notes on the European Union, Cohesion / Transport and Tourism Policy / Common transport policy: general information, European Parliament. 2020.

3. Decision No 884/2004/EC (2004) of the European Parliament and of the Council of 29 April 2004 amending Decision No 1692/96/EC on Community guidelines for the development of the trans-European transport network. 2004.

4. European Information and Documentation Centre of the Polish Parliament. Consolidated version of the Treaty on the Functioning of the European Union, Title 16: Trans-European Networks https://oide.sejm.gov.pl/ oide/index . php?option=com_content\&view=article\&id=14804\&Itemid=946\#3.16.html ..

5. Functioning of the rail transport market in 2011(2012), Warsaw: Office of Rail Transport 2012.

6. Horizontal review (2018): Improving the EU transport sector - current challenges, European Court of Auditors 2018.

7. Klimek, H. Nowa koncepcja transeuropejskiej sieci transportowej. Zeszyty Naukowe Uniwersytetu Gdańskiego. Studia i Materiały Instytutu Transportu i Handlu Morskiego 10 (2013).

8. Lipińska-Słota, A. Korytarze transportowe w nowej polityce transportowej UE. Logistyka, Uniwersytet Ekonomiczny w Katowicach, Katedra Transportu 4, 2107 (2014).

9. (ed Luttge, G.) Report on the follow-up to the Helsinki Conference on Pan-European Transport Policy, Committee on Transport and Tourism, European Parliament. (1999).

10. Ratcliff, C. Common transport policy: an overview, European Parliament 2020.

11. Regulation (EU) No 913/2010 of the European Parliament and of the Council of 22 September 2010 concerning a European rail network for competitive freight, Brussels, 22 September 2010. Multi-annual ProgrammeforRail Investments [Polish: WPIK 2012]

12. Regulation of the European Parliament and of the Council on Union guidelines for the development of the transEuropean transport network, 19 October 2011. COM (2011) 6502011.

13. TEN-T issues are currently governed by Regulation No 1315/2013 of the European Parliament and of the (EU) Council of 11 December 2013 on EU guidelines for the development of the trans-European transport network, Journal of Laws L 348 of 20.12.2013 2020. https://www.gov.pl/web/infrastruktura/transeuropejskasiec-transportowaten-t.

14. The Trans-European Transport Network - TEN-T is an instrument for the coordination, coherence and complementarity of infrastructure investments. More: Trans-European Transport Network - TEN-T, Ministry of Infrastructure of the Republic of Poland 2020. https://www.gov.pl/web/infrastruktura/transeuropejskasiec-transportowa-ten-t.

15. Transport Development Strategy to 2020 (with an outlook to 2030), Ministry of Transport, Construction and Maritime Economy 2013.

16. Wakefield, C. Reports and forecasts, 8 major European transport corridors 2019. https: //www . egospodarka . pl/153718, 8-glownych-korytarzy-transportowych-w-Europie, 1, 39, 1.html.

17. White Paper on Transport, COM (2011) 144: Roadmap to a Single European Transport Area - Towards a competitive and resource efficient transport system, Directorate-General for Mobility and Transport, European Commission, European Publications Office Luxembourg COM 144 final version of 28 March 2011. 2011.

18. Wojewódzka-Krół, K. \& Rolbiecki, R. Polityka rozwoju transportu (Wydawnictwo Uniwersytetu Gdańskiego, 2013). 